\title{
Extracts from cotton over the whole growing season induce Orobanche cumana (sunflower broomrape) germination with significant cultivar interactions
}

\author{
Ming LANG ${ }^{1,2}$, Rui YU ${ }^{3}$, Yongqing MA $(\bowtie)^{1}$, Wei ZHANG ${ }^{3}$, Christopher S. P. McErlean ${ }^{4}$ \\ 1 The State Key Laboratory of Soil Erosion and Dryland Farming, Institute of Soil and Water Conservation, \\ Northwest A\&F University, Yangling 712100, China \\ 2 College of Resources and Environmental Sciences, China Agricultural University, Beijing 100193, China \\ 3 College of Forestry, Northwest A\&F University, Yangling 712100, China \\ 4 School of Chemistry, University of Sydney, Sydney 2006, Australia
}

\begin{abstract}
Five cotton cultivars and their parents were tested for induction of germination of Orobanche cumana Wallr. (sunflower broomrape) seeds in pot and field experiments. Germination rates induced by cotton root extracts were the highest followed by stem extracts then leaf extracts. Cotton seedlings at the six-leaf stage induced higher germination than seedling at the two- and four-leaf stage, in all five cotton cultivars and their parents. In the field, the highest concentration of cotton root extracts gave the highest germination rate of $O$. cumana, and the lowest concentration of cotton root extracts gave the lowest germination rate. Methanol extracts of cotton rhizosphere soil gave the highest germination of $O$. cumana. In general, the root, stem and leaf extracts were more active at the sixleaf stage than other seedling stages. In conclusion, extracts of cotton rhizosphere soil and tissues have high activity in the seedling stage. Extracts of cotton across the whole growing season were able to induce $O$. cumana germination but displayed significant cultivar interactions.
\end{abstract}

Keywords agricultural systems, cotton, crop ecology, crop rotation systems, weed management

\section{Introduction}

Broomrapes (Orobanche spp.) are holoparasitic weeds that completely depend on their hosts for water and nutrients ${ }^{[1]}$. They heavily infest many important crops and have negative impacts on crop yield and quality, thus causing economic losses worldwide ${ }^{[2,3]}$. Of the 20 broomrape

Received December 24, 2016; accepted February 7, 2017

Correspondence: mayongqing@ms.iswc.ac.cn species in China, Phelipanche aegyptiaca Pers. (Egyptian broomrape), O. cumana Wallr. (Sunflower broomrape) and $O$. ramosa $\mathrm{L}$. are the most common and have the widest host range ${ }^{[4]}$.

Suitable temperature and moisture conditions are required for host plants (such as sunflower) to grow, but these conditions alone are not sufficient to cause $O$. cumana seeds germination. This parasite has evolved to require a chemical signal from a host or non-host plant to induce germination. In the absence of these germination stimulants, the seeds will revert back to secondary dormancy ${ }^{[2]}$.

Cotton is a non-host plant that can induce germination of clover broomrape $\mathrm{e}^{[5]}$. Botanga et al. showed that in planta production of the germination stimulant of Striga hermonthica (Del.) Benth in cotton was a qualitatively inherited trait, and the genes encoding this stimulant are monogenic and simply inherited ${ }^{[6]}$. It might therefore be possible to select and breed certain cotton genotypes that produce high concentrations of highly active germination stimulants, while maintaining or improving other agronomic attributes.

Efficient and economical control of Orobanche is extremely difficult because of the infested soil usually contains high seed reservoir densities. At present, mechanical and manual removal, pesticide spraying and other measures are used to control Orobanche, but these methods are costly and labor intensive. They also pose unwanted side effects of crop phytotoxicity and environmental pollution caused by chemical pesticide residues. Therefore, there is currently no consistent and sustainable method for controlling Orobanche anywhere in the world ${ }^{[2]}$.

Trap crops are non-host crops that induce germination of Orobanche, and consequently lead to seed reservoir 
attrition. Research has shown that many crops including carrot, cucumber, maize, onion, soybean and wheat can be used as trap crops for clover broomrape ${ }^{[7,8]}$. Wheat can be used as a trap crop with germination rates as high as $25 \%$ to $40 \%$, and even up to $70 \%{ }^{[9]}$. Control of parasitic weeds with trap crops is by far the most economical and practical method for small-scale commercial farming ${ }^{[10]}$. Our research group has conducted investigations on trap crops for Orobanche spp. including wheat ${ }^{[9,11]}$, maize ${ }^{[12]}$, cotton $^{[13]}$, soybean ${ }^{[14]}$, rice ${ }^{[15]}$ and switchgrass (Panicum virgatum $)^{[16]}$. In this study, pot and field experiments were conducted to study the effects of rhizosphere soil, root, stem and leaf extracts of different cotton cultivars on the germination of $O$. cumana. The objective was to find a new method for using cotton as a trap crop for the biocontrol of O. cumana.

\section{Materials and methods}

\subsection{Source of seeds and chemicals}

Seeds of the cotton cultivars were provided by the Cotton Institute Henan Academy of Agricultural Science. Strigol was provided by Prof. K. Yoneyama, Utsunomiya University, Japan and synthetic strigolactones GR24 by Prof. B. Zwanenburg, Radboud University, The Netherlands.

\subsection{Seed surface sterilization}

Cotton and $O$. cumana seeds were surface sterilized in $1 \%$ sodium hypochlorite for $3 \mathrm{~min}$ and then soaked in $75 \%$ $(\mathrm{V} / \mathrm{V})$ ethanol for $3 \mathrm{~min}$. After thoroughly rinsing with sterile distilled water, seeds were air-dried.

\subsection{Preconditioning of O. cumana seed}

Five milliliter gibberellin $\left(10^{-4} \mathrm{~mol} \cdot \mathrm{L}^{-1}\right)$ was added into a Petri dish (9 $\mathrm{cm}$ in diameter) containing two filter papers. Glass fiber filter disks ( $8 \mathrm{~mm}$ Whatman GF/A) were laid uniformly on the double filter paper and 20-50 O. cumana seeds placed on each disk. The Petri dishes were then sealed with Parafilm and incubated at $25^{\circ} \mathrm{C}$ for $6 \mathrm{~d}$ as described in Parker et al. ${ }^{[17]}$.

\subsection{O. cumana germination assay}

Aqueous solutions were assayed directly, by applying $20 \mu \mathrm{L}$ aliquots of the respective test solution to conditioned $O$. cumana seeds on glass fiber filter disks in the Petri dishes. For solutions and extracts containing organic solvents, aliquots $(20 \mu \mathrm{L}$ each) of the test solution were applied to an $8 \mathrm{~mm}$ disk of glass fiber filter paper without seeds and allowing it to dry. Then a disk of conditioned $O$. cumana seed was placed on top of each and moistened with $40 \mu \mathrm{L}$ of distilled water. After $10 \mathrm{~d}$ incubation, the germination rates were examined under a binocular dissecting microscope. An O. cumana seed was considered as germinated when the germ-tube protruded from the seed coat. GR24 was also used at $10 \mathrm{mg} \cdot \mathrm{L}^{-1}$ on seed stock in separate assays to establish a standard proportion of $O$. cumana seeds that were responsive to germination stimulants $^{[18]}$. A distilled water control was also included. Individual treatments were replicated three times unless otherwise mentioned.

\subsection{Field and pot experiments}

Five cotton cultivars and their parents (Table 1), were sown in both pots and field at the Institute of Soil and Water Conservation, Northwest A\&F University, Yangling, Shaanxi Province, China in May 2009. The previous crop in the field had been wheat. Five cotton hybrid cultivars and their parents were cultivated in each block, with 30 cotton seeds in a row. The plants were harvested at the two-leaf stage (May 25, 2010), four-leaf stage (June 20, 2010), six-leaf stage (July 8, 2010), squaring stage (September 10, 2010) and flowering-boll stage (October $12,2010)$. The loosely held soil was gently shaken off the roots, which was referred to as rhizosphere soil ${ }^{[19,20]}$ and the soil as well as plant samples were sampled at each stage.

Table 1 The cotton cultivars and the corresponding cotton number used in pot and field experiment

\begin{tabular}{lc}
\hline Cotton number & Cotton cultivar \\
\hline Male 1 & Zhongmiansuo 48 male parent \\
Female 1 & Zhongmiansuo 48 female parent \\
Hybrid 1 & Zhongmiansuo 48F1 \\
Male 2 & Zhongmiansuo 51 male parent \\
Female 2 & Zhongmiansuo 51 female parent \\
Hybrid 2 & Zhongmiansuo 51F1 \\
Male 3 & Zhongmiansuo 101 male parent \\
Female 3 & Zhongmiansuo 101 female parent \\
Hybrid 3 & Zhongmiansuo 101F1 \\
Male 4 & Batiao-083001 \\
Female 4 & Batiao-083001 \\
Hybrid 4 & Batiao-083001 \\
Male 5 & Qitiao-083001 \\
Female 5 & Qitiao-083001 \\
Hybrid 5 & Qitiao-083001 \\
\hline
\end{tabular}

Pot experiments were conducted at the of Institute of Soil and Water Conservation, Northwest A\&F University, Yangling, Shaanxi Province, China in May 2009. Eight kilogram of soil was put in each pot. Lou soil (Eum-orthic Anthrosols) was collected from the field at Institute of Soil 
and Water Conservation, Northwest A\&F University, with the $\mathrm{pH}$ of 7.98 , organic matter content of $14.0 \mathrm{~g} \cdot \mathrm{kg}^{-1}$, available nitrogen of $71.3 \mathrm{mg} \cdot \mathrm{kg}^{-1}$, available phosphorus of $24.2 \mathrm{mg} \cdot \mathrm{kg}^{-1}$ and available potassium of $166.0 \mathrm{mg} \cdot \mathrm{kg}^{-1}$, respectively. Twenty cotton seeds were planted into each pot $(15 \mathrm{~cm} \times 10 \mathrm{~cm})$. Each cultivar had three replications. The cotton plants were collected after $40 \mathrm{~d}$ at the six-leaf stage. Soils were sampled at the same time.

\subsection{Rhizosphere soil on O. cumana germination}

Five grams of the rhizosphere $\operatorname{soil}^{[19,20]}$ and $1.5 \mathrm{~mL}$ distilled water were added to Petri dishes $(3.5 \mathrm{~cm}$ in diameter). Five disks of glass fiber filter paper $(8 \mathrm{~mm}$ Whatman GF/A) with conditioned $O$. cumana seeds were put on the surface of the soil and the Petri dishes were sealed and incubated at $25^{\circ} \mathrm{C}$ for $10 \mathrm{~d}$ and subsequently examined for germination using a binocular dissecting microscope.

2.7 Methanol and distilled water extracts of cotton roots, stems and leaves on $O$. cumana germination

Cotton root, stem, and leaf were freeze-dried, milled and sieved $(0.35 \mathrm{~mm})$. Samples $(100 \mathrm{mg})$ were weighed into $1.5 \mathrm{~mL}$ centrifuge tubes and $1 \mathrm{~mL}$ of methanol or distilled water added. The tubes were sonicated for $30 \mathrm{~min}$ then centrifuged at $6400 \mathrm{rpm}$ for $2 \mathrm{~min}$. The supernatant was collected, and used undiluted and at 10- and 100-fold dilutions in $O$. cumana germination tests.

\subsection{Data analysis}

The germination rates among different cultivars at each growth stage were subjected to an analysis of variance. Data processing was done with Excel 2007 and DPS 9.5. Tukey's honest significant difference (HSD) test was used to compare the means.

\section{Results and discussion}

GR24 $\left(1 \mathrm{mg} \cdot \mathrm{L}^{-1}\right)$ gave the high germination rates (over $60 \%$ ) in all experiments and distilled water did not induce germination.

In pot experiments, undiluted extracts did not induce any germination, but the 100-fold dilution gave the highest germination rate, higher than that induced by the 10 -fold dilution (Table 2). Root extracts from the three cotton seedling stages (two-, four- and six-leaf stages) all induced $O$. cumana germination. There were significant interactions with cultivar and their parents. Generally, extracts from cotton plants at the six-leaf stage induced the highest germination, followed by the four-leaf stage and the twoleaf stage. The highest germination rates reached at each stage were $76.5 \%$ for Male 5 at the six-leaf stage, $68.8 \%$ for Female 4 at the four-leaf stage, and $37.7 \%$ for Female 4 at the two-leaf stage. At least five cotton cultivars and/or parents induced over $60 \%$ germination at the four- and sixleaf stages (Table 2).

There were similar trends for the methanol extracts of cotton stem and leaf. Also there were significant

Table 2 Germination rates of sunflower broomrape induced by 10- and 100-fold methanol extracts of cotton roots at two-, four- and six-leaf stages in pot experiment

\begin{tabular}{|c|c|c|c|c|c|c|}
\hline \multirow{2}{*}{ Cotton cultivar } & \multicolumn{2}{|c|}{ Two-leaf } & \multicolumn{2}{|c|}{ Four-leaf } & \multicolumn{2}{|c|}{ Six-leaf } \\
\hline & 10-fold & 100 -fold & 10-fold & 100 -fold & 10-fold & 100 -fold \\
\hline$\overline{\text { Male } 1}$ & 26.9 abcd & $38.2 \mathrm{ab}$ & $15.7 \mathrm{f}$ & $1.0 \mathrm{~cd}$ & $32.7 \mathrm{de}$ & $0.0 \mathrm{~b}$ \\
\hline Female 1 & $5.0 \mathrm{~g}$ & $19.6 \mathrm{ef}$ & $60.3 \mathrm{abc}$ & $16.3 \mathrm{bcd}$ & 54.9 abcd & $20.0 \mathrm{a}$ \\
\hline Hybrid 1 & $32.8 \mathrm{ab}$ & 30.9 abcde & $27.6 \mathrm{def}$ & $12.5 \mathrm{bcd}$ & $57.5 \mathrm{abc}$ & $24.8 \mathrm{a}$ \\
\hline Male 2 & $34.9 \mathrm{a}$ & $33.1 \mathrm{abcd}$ & $54.2 \mathrm{abc}$ & $10.8 \mathrm{bcd}$ & 39 cde & $0.0 \mathrm{~b}$ \\
\hline Female 2 & 26.2 abcde & $40.9 \mathrm{a}$ & $61.3 \mathrm{abc}$ & $16.0 \mathrm{bcd}$ & $70.7 \mathrm{a}$ & $0.0 \mathrm{~b}$ \\
\hline Hybrid 2 & $31.0 \mathrm{abc}$ & $36.2 \mathrm{abc}$ & $38.8 \mathrm{cdef}$ & 8.9 bcd & $62.2 \mathrm{ab}$ & $0.8 \mathrm{~b}$ \\
\hline Male 3 & $14.7 \mathrm{defg}$ & $16.2 \mathrm{f}$ & $20.1 \mathrm{ef}$ & $10.1 \mathrm{bcd}$ & $4.2 \mathrm{f}$ & $0.0 \mathrm{~b}$ \\
\hline Female 3 & 21.5 bcde & 25.8 bcdef & $60.6 \mathrm{abc}$ & $41.9 \mathrm{a}$ & $59.9 \mathrm{abc}$ & $0.0 \mathrm{~b}$ \\
\hline Hybrid 3 & $34.6 \mathrm{a}$ & $35.8 \mathrm{abc}$ & $49.3 \mathrm{abcd}$ & $25.6 \mathrm{ab}$ & $27.2 \mathrm{ef}$ & $0.0 \mathrm{~b}$ \\
\hline Male 4 & 26.3 abcde & $39.7 \mathrm{a}$ & 18.7 ef & $0.5 \mathrm{~d}$ & $61.8 \mathrm{abc}$ & $2.1 \mathrm{~b}$ \\
\hline Female 4 & $37.7 \mathrm{a}$ & 30.0 abcde & $68.8 \mathrm{a}$ & $21.4 \mathrm{~b}$ & 44.8 bcde & $11.8 \mathrm{ab}$ \\
\hline Hybrid 4 & $13.9 \mathrm{efg}$ & $39.1 \mathrm{a}$ & 42.3 bcde & $12.4 \mathrm{bcd}$ & $71.3 \mathrm{a}$ & $0.6 \mathrm{~b}$ \\
\hline Male 5 & $36.9 \mathrm{a}$ & $38.1 \mathrm{ab}$ & $52.7 \mathrm{abc}$ & $1.7 \mathrm{~cd}$ & $76.5 \mathrm{a}$ & $0.4 \mathrm{~b}$ \\
\hline Female 5 & $18.9 \mathrm{cdef}$ & $23.9 \mathrm{cdef}$ & $62.9 \mathrm{ab}$ & $4.1 \mathrm{~cd}$ & 41.6 bcde & $22.6 \mathrm{a}$ \\
\hline Hybrid 5 & $7.7 \mathrm{fg}$ & $22.4 \mathrm{def}$ & $38.5 \mathrm{cdef}$ & $17.7 \mathrm{bc}$ & 40.9 bcde & $0.5 \mathrm{~b}$ \\
\hline
\end{tabular}

Note: Only the means in the same column were compared. Different letters indicate significant differences between means at $P<0.05$ (Tukey's HSD). The same bellow. 
interaction with cultivar and their parents. Basically, extracts of the six-leaf stage induced the highest germination, followed by the four-leaf stage and the two-leaf stage (Table 3; Table 4).

The field experiment showed that extracts from the whole growth period of cotton, rhizosphere and tissues could induce $O$. cumana germination, but there were significant interactions with cotton cultivar (Tables 5-8).

The undiluted methanol extracts of rhizosphere soil induced the highest $O$. cumana germination compared to the 10- and 100-fold dilutions. The average germination rates were over $30 \%$ at squaring stage, with Male 1, Male 2 and Female 3 inducing over 35\% germination at this stage. In contrast to the pot experiments, the germination induced by extracts collected at squaring stage were higher than germination for the four-leaf stage, followed by the twoleaf stage and the six-leaf stage (Table 6).

The 100-fold diluted methanol extracts of rhizosphere soil gave the highest $O$. cumana germination rates compared to the undiluted and 10-fold dilutions. As for the pot experiments, the germination induced by the soils collected at the six-leaf stage were highest for the whole growth period, while the extract from the flowering-boll stage showed the lowest germination rates. The Male 2 cotton parent induced $81.0 \%$ germination at the six-leaf stage (Table 6).

The 100-fold diluted methanol extracts of stem tissues gave the highest $O$. cumana germination rates compared to the undiluted and 10-fold dilutions. Among the five stages, the average germination rates induced by the two-leaf stage samples were the highest, while those from the floweringboll stage were the lowest. The Hybrid 5 cotton induced $67.7 \%$ germination at the two-leaf stage (Table 7).

Again, the 100-fold diluted methanol leaf extract gave the highest $O$. cumana germination rates compared to the undiluted and 10-fold dilutions. Among the five stages, the germination rates induced by the extracts from the two-leaf stage were highest, while the squaring stage gave the lowest germination rates. The Female 5 cotton parent induced $53.1 \%$ germination at the two-leaf stage (Table 7).

The plants collected at flowering-boll cotton stage were divided into eight parts: root, upper stem xylem, lower part of stem xylem, upper stem phloem, and lower part of stem phloem, upper leaves, lower leaves, and flowering-boll. The methanol extracts of the tissues induced $O$. cumana germination. For nine cotton cultivars, extracts of the different organs gave the lowest germination rates. This demonstrated that the germination activity was weak at the flowering-boll stage. (Table 8)

Our observations are consistent with those of Botanga et al. ${ }^{[6]}$ that showed cotton genotypes significantly affect the induction of $O$. cumana germination. Integrated management of parasitic weeds like Orobanche using trap crops is needed to reduce the use of herbicides in agriculture. Trap cropping is done to induce the germination of parasitic weed seeds, while preventing the parasite from producing its own seeds. Orobanche produces a large number of seeds that have prolonged dormancy in the soil. A chemical stimulant is required to break the seed dormancy and induce germination. This chemical is

Table 3 Germination rates of sunflower broomrape induced by 10- and 100-fold methanol extracts of cotton stem at two-, four- and six-leaf stages in pot experiments

\begin{tabular}{|c|c|c|c|c|c|c|}
\hline \multirow{2}{*}{ Cotton cultivar } & \multicolumn{2}{|c|}{ Two-leaf } & \multicolumn{2}{|c|}{ Four-leaf } & \multicolumn{2}{|c|}{ Six-leaf } \\
\hline & 10-fold & 100 -fold & 10 -fold & 100-fold & 10-fold & 100 -fold \\
\hline Male 1 & $38.2 \mathrm{ab}$ & 26.9 abcd & $1.0 \mathrm{~cd}$ & $15.7 \mathrm{f}$ & $0.0 \mathrm{~b}$ & $32.7 \mathrm{de}$ \\
\hline Female 1 & $19.6 \mathrm{ef}$ & $5.0 \mathrm{~g}$ & $16.3 \mathrm{bcd}$ & $60.3 \mathrm{abc}$ & $20.0 \mathrm{a}$ & $54.9 \mathrm{abcd}$ \\
\hline Hybrid 1 & 30.9 abcde & $32.8 \mathrm{ab}$ & $12.5 \mathrm{bcd}$ & $27.6 \mathrm{def}$ & $24.8 \mathrm{a}$ & $57.5 \mathrm{abc}$ \\
\hline Male 2 & $33.1 \mathrm{abcd}$ & $34.9 \mathrm{a}$ & $10.8 \mathrm{bcd}$ & $54.2 \mathrm{abc}$ & $0.0 \mathrm{~b}$ & 39 cde \\
\hline Female 2 & $40.9 \mathrm{a}$ & 26.2 abcde & $16.0 \mathrm{bcd}$ & $61.3 \mathrm{abc}$ & $0.0 \mathrm{~b}$ & $70.7 \mathrm{a}$ \\
\hline Hybrid 2 & $36.2 \mathrm{abc}$ & $31.0 \mathrm{abc}$ & $8.9 \mathrm{bcd}$ & 38.8 cdef & $0.8 \mathrm{~b}$ & $62.2 \mathrm{ab}$ \\
\hline Male 3 & $16.2 \mathrm{f}$ & $14.7 \mathrm{defg}$ & $10.1 \mathrm{bcd}$ & $20.1 \mathrm{ef}$ & $0.0 \mathrm{~b}$ & $4.2 \mathrm{f}$ \\
\hline Female 3 & $25.8 \mathrm{bcdef}$ & 21.5 bcde & $41.9 \mathrm{a}$ & $60.6 \mathrm{abc}$ & $0.0 \mathrm{~b}$ & $59.9 \mathrm{abc}$ \\
\hline Hybrid 3 & $35.8 \mathrm{abc}$ & $34.6 \mathrm{a}$ & $25.6 \mathrm{ab}$ & $49.3 \mathrm{abcd}$ & $0.0 \mathrm{~b}$ & $27.2 \mathrm{ef}$ \\
\hline Male 4 & $39.7 \mathrm{a}$ & 26.3 abcde & $0.5 \mathrm{~d}$ & 18.7 ef & $2.1 \mathrm{~b}$ & $61.8 \mathrm{abc}$ \\
\hline Female 4 & 30.0 abcde & $37.7 \mathrm{a}$ & $21.4 \mathrm{~b}$ & $68.8 \mathrm{a}$ & $11.8 \mathrm{ab}$ & 44.8 bcde \\
\hline Hybrid 4 & $39.1 \mathrm{a}$ & 13.9 efg & $12.4 \mathrm{bcd}$ & 42.3 bcde & $0.6 \mathrm{~b}$ & $71.3 \mathrm{a}$ \\
\hline Male 5 & $38.1 \mathrm{ab}$ & $36.9 \mathrm{a}$ & $1.7 \mathrm{~cd}$ & $52.7 \mathrm{abc}$ & $0.4 \mathrm{~b}$ & $76.5 \mathrm{a}$ \\
\hline Female 5 & $23.9 \mathrm{cdef}$ & $18.9 \mathrm{cdef}$ & $4.1 \mathrm{~cd}$ & $62.9 \mathrm{ab}$ & $22.6 \mathrm{a}$ & 41.6 bcde \\
\hline Hybrid 5 & $22.4 \mathrm{def}$ & $7.7 \mathrm{fg}$ & $17.7 \mathrm{bc}$ & $38.5 \mathrm{cdef}$ & $0.5 \mathrm{~b}$ & 40.9 bcde \\
\hline
\end{tabular}


Table 4 Germination rates of sunflower broomrape induced by 10-fold methanol extracts of cotton leaf at two-, four- and six-leaf stages in pot experiments

\begin{tabular}{|c|c|c|c|}
\hline Cotton cultivar & Two-leaf & Four-leaf & Six-leaf \\
\hline Male 1 & $38.2 \mathrm{ab}$ & $1.0 \mathrm{~cd}$ & $0.0 \mathrm{~b}$ \\
\hline Female 1 & $19.6 \mathrm{ef}$ & $16.3 \mathrm{bcd}$ & $20.0 \mathrm{a}$ \\
\hline Hybrid 1 & 30.9 abcde & $12.5 \mathrm{bcd}$ & $24.8 \mathrm{a}$ \\
\hline Male 2 & $33.1 \mathrm{abcd}$ & $10.8 \mathrm{bcd}$ & $0.0 \mathrm{~b}$ \\
\hline Female 2 & $40.9 \mathrm{a}$ & $16.0 \mathrm{bcd}$ & $0.0 \mathrm{~b}$ \\
\hline Hybrid 2 & $36.2 \mathrm{abc}$ & $8.9 \mathrm{bcd}$ & $0.8 \mathrm{~b}$ \\
\hline Male 3 & $16.2 \mathrm{f}$ & $10.1 \mathrm{bcd}$ & $0.0 \mathrm{~b}$ \\
\hline Female 3 & $25.8 \mathrm{bcdef}$ & $41.9 \mathrm{a}$ & $0.0 \mathrm{~b}$ \\
\hline Hybrid 3 & $35.8 \mathrm{abc}$ & $25.6 \mathrm{ab}$ & $0.0 \mathrm{~b}$ \\
\hline Male 4 & $39.7 \mathrm{a}$ & $0.5 \mathrm{~d}$ & $2.1 \mathrm{~b}$ \\
\hline Female 4 & 30.0 abcde & $21.4 \mathrm{~b}$ & $11.8 \mathrm{ab}$ \\
\hline Hybrid 4 & $39.1 \mathrm{a}$ & $12.4 \mathrm{bcd}$ & $0.6 \mathrm{~b}$ \\
\hline Male 5 & $38.1 \mathrm{ab}$ & $1.7 \mathrm{~cd}$ & $0.4 \mathrm{~b}$ \\
\hline Female 5 & $23.9 \mathrm{cdef}$ & $4.1 \mathrm{~cd}$ & $22.6 \mathrm{a}$ \\
\hline Hybrid 5 & $22.4 \mathrm{def}$ & $17.7 \mathrm{bc}$ & $0.5 \mathrm{~b}$ \\
\hline
\end{tabular}

Table 5 Germination rates of sunflower broomrape induced by methanol extracts of cotton rhizosphere soils at five stages in field experiments

\begin{tabular}{|c|c|c|c|c|c|}
\hline Cotton cultivars & Two-leaf & Four-leaf & Six-leaf & Squaring & Flowering-boll \\
\hline$\overline{\text { Male } 1}$ & $36.0 \mathrm{a}$ & $0.0 \mathrm{~h}$ & $26.9 \mathrm{bcd}$ & $39.3 \mathrm{ab}$ & $0.0 \mathrm{~b}$ \\
\hline Female 1 & $32.1 \mathrm{ab}$ & $10.1 \mathrm{fgh}$ & $4.8 \mathrm{e}$ & $31.8 \mathrm{abc}$ & $4.6 \mathrm{~b}$ \\
\hline Hybrid 1 & $4.7 \mathrm{de}$ & $16.1 \mathrm{efg}$ & $0.0 \mathrm{e}$ & $28.1 \mathrm{abc}$ & $16.9 \mathrm{a}$ \\
\hline Male 2 & $13.6 \mathrm{cde}$ & $38.8 \mathrm{ab}$ & $15.9 \mathrm{de}$ & $36.1 \mathrm{abc}$ & $15.6 \mathrm{a}$ \\
\hline Female 2 & $26.9 \mathrm{abc}$ & $8.7 \mathrm{fgh}$ & $46.7 \mathrm{a}$ & $24.7 \mathrm{bc}$ & $9.5 \mathrm{ab}$ \\
\hline Hybrid 2 & $5.9 \mathrm{de}$ & $20.4 \mathrm{cdef}$ & $0.0 \mathrm{e}$ & $27.3 \mathrm{abc}$ & $8.3 \mathrm{ab}$ \\
\hline Male 3 & $4.3 \mathrm{de}$ & $31.3 \mathrm{abc}$ & $33.9 \mathrm{abc}$ & $34.1 \mathrm{abc}$ & $0.0 \mathrm{~b}$ \\
\hline Female 3 & $6.1 \mathrm{de}$ & $10.7 \mathrm{fgh}$ & $9.3 \mathrm{e}$ & $35.6 \mathrm{abc}$ & $0.0 \mathrm{~b}$ \\
\hline Hybrid 3 & $34.2 \mathrm{ab}$ & $6.3 \mathrm{gh}$ & $16.6 \mathrm{cde}$ & $24.3 \mathrm{bc}$ & $0.0 \mathrm{~b}$ \\
\hline Male 4 & $21.8 \mathrm{abcd}$ & $29.5 \mathrm{bcd}$ & $1.9 \mathrm{e}$ & $28.7 \mathrm{abc}$ & $14.5 \mathrm{a}$ \\
\hline Female 4 & $1.9 \mathrm{e}$ & $18.2 \mathrm{defg}$ & $0.0 \mathrm{e}$ & $22.1 \mathrm{bc}$ & $0.0 \mathrm{~b}$ \\
\hline Hybrid 4 & 17.6 bcde & $37.3 \mathrm{ab}$ & $0.0 \mathrm{e}$ & $27.7 \mathrm{abc}$ & $0.0 \mathrm{~b}$ \\
\hline Male 5 & $28.9 \mathrm{abc}$ & $33.9 \mathrm{ab}$ & $37.7 \mathrm{ab}$ & $34.9 \mathrm{abc}$ & $0.0 \mathrm{~b}$ \\
\hline Female 5 & $13.2 \mathrm{cde}$ & $42.7 \mathrm{a}$ & $4.2 \mathrm{e}$ & $16.8 \mathrm{c}$ & $0.0 \mathrm{~b}$ \\
\hline Hybrid 5 & $0.0 \mathrm{e}$ & 27.1 bcde & $2.3 \mathrm{e}$ & $46.0 \mathrm{a}$ & $0.0 \mathrm{~b}$ \\
\hline
\end{tabular}

synthesized in planta and released as root exudates by hosts of the parasitic weed and other plants, and the latter can serve as trap crops. The primary consideration in parasitic weed management is the reduction of the parasitic weed seed reservoir in the soil ${ }^{[21]}$.

The high heritability and simple inheritance of suicidal germination in S. hermonthica under cotton suggests that this cotton trait should be easily incorporated into cultivars with good agronomic attributes for use in Striga-infested areas ${ }^{[6]}$. It has been reported that the production of strigol by proso millet gradually increased, reaching a maximum of $25 \mathrm{pg}$ per plant per day on days $5-7$, and then decreased 
Table 6 Germination rates of sunflower broomrape induced by 100-fold dilution methanol extracts of cotton stems at five stages in field experiments

\begin{tabular}{|c|c|c|c|c|c|}
\hline Cotton cultivars & Two-leaf & Four-leaf & Six-leaf & Squaring & Flowering-boll \\
\hline Male 1 & $3.1 \mathrm{~d}$ & $0.0 \mathrm{f}$ & 31.6 abcde & $6.7 \mathrm{gh}$ & $0.0 \mathrm{e}$ \\
\hline Female 1 & $38.7 \mathrm{abc}$ & $61.1 \mathrm{a}$ & 26.7 bcde & $27.1 \mathrm{def}$ & $21.1 \mathrm{c}$ \\
\hline Hybrid 1 & $22.2 \mathrm{bcd}$ & 7.6 ef & $47.8 \mathrm{ab}$ & $26.8 \mathrm{def}$ & $36.5 \mathrm{~b}$ \\
\hline Male 2 & $38.3 \mathrm{abc}$ & $0.0 \mathrm{f}$ & $43.9 \mathrm{abc}$ & $42.7 \mathrm{bcd}$ & $81.0 \mathrm{a}$ \\
\hline Female 2 & $42.9 \mathrm{abc}$ & $0.0 \mathrm{f}$ & $21.6 \mathrm{de}$ & $9.0 \mathrm{gh}$ & $7.4 \mathrm{de}$ \\
\hline Hybrid 2 & $42.4 \mathrm{abc}$ & $43.1 \mathrm{bc}$ & $41.9 \mathrm{abcd}$ & $0.0 \mathrm{~h}$ & $22.5 \mathrm{c}$ \\
\hline Male 3 & $31.4 \mathrm{bc}$ & $4.5 \mathrm{f}$ & $19.2 \mathrm{e}$ & $0.0 \mathrm{~h}$ & $0.0 \mathrm{e}$ \\
\hline Female 3 & $30.7 \mathrm{bc}$ & $12.1 \mathrm{ef}$ & $50.0 \mathrm{a}$ & $68.3 \mathrm{a}$ & $0.0 \mathrm{e}$ \\
\hline Hybrid 3 & $19.4 \mathrm{~cd}$ & $31.3 \mathrm{bcd}$ & $52.6 \mathrm{a}$ & $20.4 \mathrm{efg}$ & $0.0 \mathrm{e}$ \\
\hline Male 4 & $32.5 \mathrm{bc}$ & $38.5 \mathrm{bcd}$ & $41.2 \mathrm{abcd}$ & $45.9 \mathrm{bc}$ & $2.2 \mathrm{e}$ \\
\hline Female 4 & $29.8 \mathrm{bc}$ & $45.8 \mathrm{ab}$ & $11.0 \mathrm{e}$ & $15.1 \mathrm{fgh}$ & $12.8 \mathrm{cde}$ \\
\hline Hybrid 4 & $44.3 \mathrm{ab}$ & $23.3 \mathrm{de}$ & $46.5 \mathrm{ab}$ & $26.1 \mathrm{ef}$ & $45.2 \mathrm{~b}$ \\
\hline Male 5 & $46.2 \mathrm{ab}$ & $0.0 \mathrm{f}$ & $50.2 \mathrm{a}$ & 31.3 cde & $12.3 \mathrm{cde}$ \\
\hline Female 5 & $38.9 \mathrm{abc}$ & $33.7 \mathrm{bcd}$ & $10.2 \mathrm{e}$ & $45.4 \mathrm{bc}$ & $0.0 \mathrm{e}$ \\
\hline Hybrid 5 & $60.8 \mathrm{a}$ & $28.5 \mathrm{~cd}$ & $22.9 \mathrm{cde}$ & $49.6 \mathrm{~b}$ & $19.4 \mathrm{~cd}$ \\
\hline
\end{tabular}

Table 7 Germination rates of sunflower broomrape induced by 100-fold dilution methanol extracts of cotton leaves at five stages in field experiments

\begin{tabular}{|c|c|c|c|c|c|}
\hline Cotton cultivars & Two-leaf & Four-leaf & Six-leaf & Squaring & Flowering-boll \\
\hline Male 1 & 31.1 cdef & $52.8 \mathrm{a}$ & 35.1 bcde & $30.2 \mathrm{ab}$ & $0.0 \mathrm{e}$ \\
\hline Female 1 & $8.2 \mathrm{hi}$ & $0.0 \mathrm{~d}$ & $49.7 \mathrm{abcd}$ & $22.4 \mathrm{bc}$ & $21.1 \mathrm{c}$ \\
\hline Hybrid 1 & $27.5 \mathrm{efg}$ & $13.3 \mathrm{bc}$ & $20.5 \mathrm{de}$ & $0.9 \mathrm{e}$ & $36.5 \mathrm{~b}$ \\
\hline Male 2 & $22.6 \mathrm{fgh}$ & $0.0 \mathrm{~d}$ & $62.5 \mathrm{ab}$ & $0.0 \mathrm{e}$ & $81.0 \mathrm{a}$ \\
\hline Female 2 & $0.0 \mathrm{i}$ & $0.0 \mathrm{~d}$ & $55.9 \mathrm{abc}$ & $38.6 \mathrm{a}$ & $7.4 \mathrm{de}$ \\
\hline Hybrid 2 & $68.4 \mathrm{a}$ & $0.0 \mathrm{~d}$ & 32.3 bcde & $1.7 \mathrm{e}$ & $22.5 \mathrm{c}$ \\
\hline Male 3 & $6.4 \mathrm{i}$ & $22.1 \mathrm{~b}$ & $19.2 \mathrm{de}$ & $2.1 \mathrm{e}$ & $0.0 \mathrm{e}$ \\
\hline Female 3 & 28.7 defg & $0.0 \mathrm{~d}$ & 28.9 cde & $14.1 \mathrm{cde}$ & $0.0 \mathrm{e}$ \\
\hline Hybrid 3 & $22.5 \mathrm{fgh}$ & $0.0 \mathrm{~d}$ & 27.1 cde & $5.8 \mathrm{de}$ & $0.0 \mathrm{e}$ \\
\hline Male 4 & $26.5 \mathrm{fg}$ & $4.4 \mathrm{~cd}$ & $56.7 \mathrm{abc}$ & $19.2 \mathrm{bcd}$ & $2.2 \mathrm{e}$ \\
\hline Female 4 & 14.6 ghi & $10.5 \mathrm{bcd}$ & 32.2 bcde & $32.3 \mathrm{ab}$ & $12.8 \mathrm{cde}$ \\
\hline Hybrid 4 & $44.1 \mathrm{bcd}$ & $0.0 \mathrm{~d}$ & $40.1 \mathrm{abcd}$ & $11.7 \mathrm{cde}$ & $45.2 \mathrm{~b}$ \\
\hline Male 5 & 42.8 bcde & $0.0 \mathrm{~d}$ & $22.3 \mathrm{de}$ & $0.0 \mathrm{e}$ & $12.3 \mathrm{cde}$ \\
\hline Female 5 & $53.1 \mathrm{ab}$ & $9.0 \mathrm{bcd}$ & $7.7 \mathrm{e}$ & $0.0 \mathrm{e}$ & $0.0 \mathrm{e}$ \\
\hline Hybrid 5 & $46.9 \mathrm{bc}$ & $21.7 \mathrm{~b}$ & $67.7 \mathrm{a}$ & $0.0 \mathrm{e}$ & $19.4 \mathrm{~cd}$ \\
\hline
\end{tabular}

to a constant level of 14 pg per plant per day ${ }^{[22]}$. Strigol is produced by cotton, and is a germination stimulant for the root parasitic plants, Striga and Orobanche, which was first isolated by Cook et al. ${ }^{[23,24]}$. Strigol was later identified in the root exudates of sorghum, maize and proso millet [Pennisetum glaucum (L.) R. Br. $]^{[25]}$.
Recently, the quantification of strigolactones produced by cotton was reported, which confirmed that strigol was the main stimulant for the germination of Striga and Orobanche seeds ${ }^{[22]}$.

Since the Striga germination stimulant strigol was isolated from cotton, and in our experiment we observed 
Table 8 Germination rates of sunflower broomrape induced by 100 -fold dilution methanol extracts of various cotton tissues at boll period in field experiments

\begin{tabular}{|c|c|c|c|c|c|c|c|c|}
\hline Cotton cultivars & Root & Up stem & Low stem & Up phloem & Low phloem & Up leaves & Low leaves & Flowering-boll \\
\hline Male 1 & $0 \mathrm{~d}$ & $44.2 \mathrm{a}$ & $0 \mathrm{e}$ & $18.8 \mathrm{~b}$ & $0 \mathrm{e}$ & $0 \mathrm{e}$ & $0 \mathrm{~d}$ & $0 \mathrm{c}$ \\
\hline Female 1 & $56.2 \mathrm{~b}$ & $53.5 \mathrm{a}$ & $44.1 \mathrm{ab}$ & $7.9 \mathrm{~cd}$ & $21.1 \mathrm{c}$ & $21.1 \mathrm{c}$ & $6.0 \mathrm{c}$ & $18.8 \mathrm{a}$ \\
\hline Hybrid 1 & $32.4 \mathrm{c}$ & $0 \mathrm{~b}$ & $41.4 \mathrm{abc}$ & $0 \mathrm{~d}$ & $36.5 \mathrm{~b}$ & $36.5 \mathrm{~b}$ & $19.1 \mathrm{~b}$ & $18.9 \mathrm{a}$ \\
\hline Male 2 & $77.2 \mathrm{a}$ & $53.7 \mathrm{a}$ & $23.7 \mathrm{~cd}$ & $31.4 \mathrm{a}$ & $81.0 \mathrm{a}$ & $81.0 \mathrm{a}$ & $81.0 \mathrm{a}$ & $3.7 \mathrm{bc}$ \\
\hline Female 2 & $0 \mathrm{~d}$ & $6.4 \mathrm{~b}$ & 60.6 a & $10.2 \mathrm{c}$ & $7.4 \mathrm{de}$ & $7.4 \mathrm{de}$ & $6.5 \mathrm{c}$ & $9.2 \mathrm{~b}$ \\
\hline Hybrid 2 & $56.2 \mathrm{~b}$ & $55.2 \mathrm{a}$ & $50.8 \mathrm{a}$ & $21.5 \mathrm{~b}$ & $22.5 \mathrm{c}$ & $22.5 \mathrm{c}$ & $0 \mathrm{~d}$ & $0.8 \mathrm{c}$ \\
\hline Male 3 & $0 \mathrm{~d}$ & $0 \mathrm{~b}$ & $0 \mathrm{e}$ & $0 \mathrm{~d}$ & $0 \mathrm{e}$ & $0 \mathrm{e}$ & $0 \mathrm{~d}$ & $0 \mathrm{c}$ \\
\hline Female 3 & $0 \mathrm{~d}$ & $0 \mathrm{~b}$ & $0 \mathrm{e}$ & $0 \mathrm{~d}$ & $0 \mathrm{e}$ & $0 \mathrm{e}$ & $0 \mathrm{~d}$ & $0 \mathrm{c}$ \\
\hline Hybrid 3 & $0 \mathrm{~d}$ & $0 \mathrm{~b}$ & $0 \mathrm{e}$ & $0 \mathrm{~d}$ & $0 \mathrm{e}$ & $0 \mathrm{e}$ & $0 \mathrm{~d}$ & $0 \mathrm{c}$ \\
\hline Male 4 & $0 \mathrm{~d}$ & $1.8 \mathrm{~b}$ & $30.0 \mathrm{bc}$ & $0 \mathrm{~d}$ & $2.2 \mathrm{e}$ & $2.2 \mathrm{e}$ & $0 \mathrm{~d}$ & $0 \mathrm{c}$ \\
\hline Female 4 & $0 \mathrm{~d}$ & $0.5 \mathrm{~b}$ & $0 \mathrm{e}$ & $0 \mathrm{~d}$ & $12.8 \mathrm{cde}$ & $12.8 \mathrm{cde}$ & $0 \mathrm{~d}$ & $0 \mathrm{c}$ \\
\hline Hybrid 4 & $0 \mathrm{~d}$ & $4.9 \mathrm{~b}$ & $6 \mathrm{de}$ & $20.1 \mathrm{~b}$ & $45.2 \mathrm{~b}$ & $45.2 \mathrm{~b}$ & $0 \mathrm{~d}$ & $7.9 \mathrm{bc}$ \\
\hline Male 5 & $40.7 \mathrm{bc}$ & $0 \mathrm{~b}$ & $7.2 \mathrm{de}$ & $7.2 \mathrm{~cd}$ & $12.3 \mathrm{cde}$ & $12.3 \mathrm{cde}$ & $0 \mathrm{~d}$ & $0 \mathrm{c}$ \\
\hline Female 5 & 49.6 b & $11.4 \mathrm{~b}$ & $0 \mathrm{e}$ & $1.4 \mathrm{~d}$ & $0 \mathrm{e}$ & $0 \mathrm{e}$ & $1.8 \mathrm{~d}$ & $0.9 \mathrm{c}$ \\
\hline Hybrid 5 & $3.3 \mathrm{~d}$ & $48.9 \mathrm{a}$ & $3.2 \mathrm{e}$ & $0 \mathrm{~d}$ & $19.4 \mathrm{~cd}$ & $19.4 \mathrm{~cd}$ & $0 \mathrm{~d}$ & $0 \mathrm{c}$ \\
\hline
\end{tabular}

that the extracts from each growth stage induced $O$. cumana germination, we conclude that strigol is continuously produced during the entire growth stage.

Dor et al. ${ }^{[26]}$ found the fast-neutron-mutagenized tomato mutant, SL-ORT1 was highly resistant to various Phelipanche and Orobanche spp., but no toxic activity or inhibition of Phelipanche germination was detected in the SL-ORT1 root extracts. They concluded that the SL-ORT1 resistance was due to its inability to produce and secrete natural germination stimulants into the rhizosphere ${ }^{[26]}$. This conclusion suggested that resistance to the parasites was due to the inability of the host plant to produce germination stimulants. Recently, it was reported that the resistance of sunflower to $O$. cumana might be associated with a hypersensitive reaction which was activated by exogenous salicylic acid treatment ${ }^{[27]}$. In contrast, in our experiments all the tested cotton cultivars were able to produce $O$. cumana germination stimulants, albeit with significant cultivar interactions (Table 2; Table 5; Table 6). Importantly, however, it was observed that not all cotton cultivars were able to induce $O$. cumana germinate under the pot and field experiment conditions.

Strigolactones, including strigol, can stimulate branching of arbuscular mycorrhizal fungi ${ }^{[28]}$ and inhibit shoot branching in plants ${ }^{[29,30]}$, and so the consensus is that most of the strigolactone-producing plants $(80 \%$ of all land vegetation) could be used as trap crops for broomrapes. In reality, the situation is far more complex. Broomrape germination induced by strigolactones is an allelopathic phenomenon. Therefore the strigolactones produced in planta have to be released into the soil in suitable quantities to reach concentrations able to induce germination of parasitic weeds under various environmental stresses. As we gain greater knowledge of allelopathy and trap cropping for broomrape control, new questions arise. Further research to understand the required concentration and 3-dimensional structure of strigolactones; how they are released into the environment; their stability in any given environment; how they are translocated; how they are degraded in soil or fixed in organic soil matter; the effect of the stage of host and/or non-host plant production; local soil temperature, moisture, and mineral conditions; and how strigolactones are adsorbed by broomrape seeds, is required. Answering these questions is of paramount importance. In addition, the criteria used to recommend crop cultivars to farmers as trap crops for broomrape is complicated by the fact that each crop have numerous cultivars, and many of them may not be able to induce broomrape germination. Transferring knowledge about trap crops and allelopathy for broomrape weed control to individual farmers remains a major challenge.

\section{Conclusions}

The pot experiment indicated that there were significant interactions with cotton cultivar. Specifically, germination induced by the samples collected at the six-leaf stage was the highest, followed by the four-leaf stage and the twoleaf stage. The field experiment showed that extracts over the whole growth period of the cotton, rhizosphere and tissues were capable of inducing $O$. cumana germination, 
and that there were significant interactions with cultivar with the flowering-boll stage being the least active. These results show that cotton can be used as a trap crop to control O. cumana.

Acknowledgements The authors thank the Xinjiang Production and Construction Corps for the Year 2016 Agricultural and Social Development Science and Technology Program (2016AC007) for financial support.

Compliance with ethics guidelines Ming Lang, Rui Yu, Yongqing Ma, Wei Zhang, and Christopher S. P. McErlean declare that they have no conflict of interest or financial conflicts to disclose.

This article does not contain any studies with human or animal subjects performed by any of the authors.

\section{References}

1. Young N D, Steiner K E, Pamphilis C. The evolution of parasitism in Scrophulariaceae/Orobanchaceae: plastid gene sequences refute an evolutionary transition series. Annals of the Missouri Botanical Garden, 1999, 86(4): 876-893

2. Parker C, Riches C R. Parasitic weeds of the world biology and control. In: Gutteridge R C, Skelton H M, eds. In Orobanche species. Cambridge: Cambridge University Press, 1993, 111-164

3. Sauerborn J. The economic importance of the phytoparasites Orobanche and Striga. In: Ransom J K, Musselman L J, Worsham A D, Parker C, eds. Proceedings of the 5th International Symposium on Parasitic Weeds. Kenya: Nairobi, 1991, 137-143

4. Zhang J L, Jiang Q. The host and distribution of some important species of Orobanche and Cuscuta. Plant Quarantine, 1994, 8(2): 69-73 (in Chinese)

5. Carson A G. Studies on Striga in Gambia. In: Robson T O, Broad H R, eds. Consultation on Striga Control. Protection of the FAO/OAU All-African Government, Cameroon: FAO, 1988, 37-43

6. Botanga C J, Alabi S O, Echekwu C A. Genetics of suicidal germination of Striga hermonthica (Del.) Benth by cotton. Crop Science, 2003, 43(2): 483-488

7. Lins R D, Colquhoun J B, Cole C M, Mallory-Smith C A. Investigation of wheat as a trap crop for control of Orobanche minor. Weed Research, 2006, 46(4): 313-318

8. Yoneyama K, Takeuchi Y, Yokota T. Natural germination stimulants for Orobanche minor Sm. In: Fer A, Thalouarn P, Joel D M, Musselman L J, Parker C, Verkleij J A C, eds. Proceedings of the 7th International Symposium on Parasitic Weed. Nantes, France: University of Nantes, 2001, 123

9. Dong S Q, Ma Y Q, Wu H W, Shui J F, Ye X X, An Y. Allelopathic stimulatory effects of wheat differing in ploidy levels on Orobanche minor germination. Allelopathy Journal, 2013, 31(2): 355-366

10. Aalders A, Pieters G R. Resistance in Vicia faba to Orobanche crenata: true resistance versus hidden susceptibility. Euphytica, 1987, 36(1): 227-236

11. Dong S Q, Ma Y Q, Wu H W, Shui J F, Hao Z Q. Stimulatory effects of wheat (Triticum aestivum L.) on seed germination of Orobanche minor Sm. Allelopathy Journal, 2012, 30(2): 247-258

12. Ma Y Q, Jia J N, Wang Z, An Y, Shui J F, Mao J C. Potential of some hybrid maize lines to induce germination of sunflower broomrape. Crop Science, 2013, 53(1): 260-270
13. Ma Y Q, Lang M, Dong S Q, Shui J F, Zhao J X. Screening of some cotton varieties for allelopathic potential on clover broomrape germination. Agronomy Journal, 2012, 104(3): 569-574

14. Zhang W, Ma Y, Wang Z, Ye X, Shui J. Some soybean cultivars have ability to induce germination of sunflower broomrape. PLoS One, 2013, 8(3): e59715

15. Ma Y Q, Zhang M, Li Y L, Shui J F, Zhou Y J. Allelopathy of rice (Oryza sativa L.) root exudates and its relations with Orobanche cumana Wallr. and Orobanche minor Sm. germination. Journal of Plant Interactions, 2014, 9(1): 722-730

16. An Y, Ma Y Q, Shui J F, Zhong W J. Switchgrass (Panicum virgatum L.) has ability to induce germination of Orobanche cumana. Journal of Plant Interactions, 2015, 10(1): 142-151

17. Parker C, Hitchcock A M, Ramaiah K V. The germination of Striga species by crop root exudates: techniques for selecting resistant crop cultivars. In: Proceedings of the 6th Conference on Asian-Pacific Weed Science Society 1977, Jakarta: Weed Science Society of AsianPacific, 1977, 67-74

18. Mangnus E M, Stommen P L A, Zwanenburg B. A standardized bioassay for evaluation of potential germination stimulants for seeds of parasitic weeds. Journal of Plant Growth Regulation, 1992, 11 (2): $91-98$

19. Riley D, Barber S A. Bicarbonate accumulation and $\mathrm{pH}$ changes at the soybean (Glycine $\max$ (L.) Merr.) root-soil interface. Soil Science Society of America Journal, 1969, 33(6): 905-908

20. Riley D, Barber S A. Salt accumulation at the soybean (Glycine max (L.) Merr.) root-soil interface. Soil Science Society of America Journal, 1970, 34(1): 154-155

21. Joel D M, Steffens J C, Matthews D E. Germination of weedy root parasites. In: Kigel J, Galili G, eds. Seed development and germination. New York: Marcel Dekker, 1995, 567-597

22. Sato D, Awad A A, Takeuchi Y, Yoneyama K. Confirmation and quantification of strigolactones, germination stimulants for root parasitic plants Striga and Orobanche, produced by cotton. Bioscience, Biotechnology, and Biochemistry, 2005, 69(1): 98-102

23. Cook C E, Whichard L P, Wall M E, Egley G H, Coggon P, Luhan P A, McPhail A T. Germination stimulants II. The structure of strigola potent seed germination stimulant for witchweed (Striga lutea Lour.). Journal of the American Chemical Society, 1972, 94(17): 6198-6199

24. Cook C E, Whichard L P, Turner B, Wall M E, Egley G H. Germination of witchweed (Striga lutea Lour.): isolation and properties of a potent stimulant. Science, 1966, 154(3753): 11891190

25. Siame B P, Weerasuriya Y, Wood K, Ejeta G, Butler L G. Isolation of strigol, a germination stimulant for Striga asiatica from host plants. Journal of Agricultural and Food Chemistry, 1993, 41(9): 1486-1491

26. Dor E, Yoneyama K, Wininger S, Kapulnik Y, Yoneyama K, Koltai $\mathrm{H}, \mathrm{Xie} \mathrm{X}$, Hershenhorn J. Strigolactone deficiency confers resistance in tomato line SL-ORT1 to the parasitic weeds Phelipanche and Orobanche spp. Phytopathology, 2011, 101(2): 213-222

27. Yang C, Hu L Y, Ali B, Islam F, Bai Q J, Xun X P, Yoneyama K, Zhou W J. Seed treatment with salicylic acid invokes defense mechanism of Helianthus annuus against Orobanche cumana. Annals of Applied Biology, 2016, 169(3): 408-422 
28. Akiyama K, Matsuzaki K, Hayashi H. Plant sesquiterpenes induce hyphal branching in arbuscular mycorrhizal fungi. Nature, 2005, 435(7043): 824-827

29. Gomez-Roldan V, Fermas S, Brewer P B, Puech-Pagès V, Dun E A, Pillot J P, Letisse F, Matusova R, Danoun S, Portais J C, Bouwmeester $\mathrm{H}, \mathrm{B}^{\circ} \mathrm{Card} \mathrm{G}$, Beveridge $\mathrm{C}$ A, Rameau C, Rochange
S F. Strigolactone inhibition of shoot branching. Nature, 2008, 455 (7210): 189-194

30. Umehara M, Hanada A, Yoshida S, Akiyama K, Arite T, TakedaKamiya N, Magome H, Kamiya Y, Shirasu K, Yoneyama K, Kyozuka J, Yamaguchi S. Inhibition of shoot branching by new terpenoid plant hormones. Nature, 2008, 455(7210): 195-200 